\title{
Apoptotic markers in a prostate cancer cell line: Effect of ellagic acid
}

\author{
LUCA VANELLA $^{1}$, CLAUDIA DI GIACOMO ${ }^{1}$, ROSARIA ACQUAVIVA ${ }^{1}$, IGNAZIO BARBAGALLO ${ }^{1}$, \\ VENERA CARDILE $^{2}$, DONG HYUN KIM ${ }^{3}$, NADER G. ABRAHAM ${ }^{3}$ and VALERIA SORRENTI ${ }^{1}$ \\ ${ }^{1}$ Department of Drug Science, Section of Biochemistry, and ${ }^{2}$ Department of Bio-Medical Sciences, \\ Section of Physiology, University of Catania, I-95125 Catania, Italy; ${ }^{3}$ Joan C. Edwards \\ School of Medicine, Marshall University, Huntington, WV 25701, USA
}

Received June 25, 2013; Accepted August 12, 2013

DOI: $10.3892 /$ or.2013.2757

\begin{abstract}
Ellagic acid (EA) inhibits cell growth and induces apoptosis in cultured cells; however, the precise molecular mechanism involved in EA-induced apoptosis in prostate cancer cells is unknown. The aim of the present study was to delineate possible apoptotic pathway(s) involved in the EA-mediated chemotherapeutic effects in the LNCaP human prostatic cancer cell line. EA produced anti-proliferative effects through inhibition of rapamycin (mTOR) activation and a reduction in intracellular levels of $\beta$-catenin. Moreover, we demonstrated that EA induced apoptosis via downregulation of the anti-apoptotic proteins, silent information regulator 1 (SIRT1), human antigen R (HuR) and heme oxygenase-1 (HO-1). EA modulated the expression of apoptosis-inducing factor (AIF) resulting in a significant increase in reactive oxygen species (ROS) levels and the activation of caspase-3. Finally, we demonstrated that EA reduced both transforming growth factor- $\beta$ (TGF- $\beta$ ) and interleukin-6 (IL-6) levels. EA treatment resulted in the increased expression of the tumor suppressor protein p21 and increased the percentage of apoptotic cells. In conclusion, the results suggest that EA treatment represents a new and highly effective strategy in reducing prostate cancer carcinogenesis.
\end{abstract}

\section{Introduction}

Prostate cancer (PC) is the most common cancer in men over the age of 50 years. PC represents one of the leading causes of cancer-related mortality in Western countries (1-3) and is associated with the most rapidly increasing rate of diagnosis in Japanese men (4). Thus, it is essential to clearly delineate the risk factors, diagnosis, treatment options and emerging

Correspondence to: Professor Valeria Sorrenti, Department of Drug Science, Section of Biochemistry University of Catania, Viale A. Doria 6, I-95125 Catania, Italy

E-mail: sorrenti@unict.it

Key words: ellagic acid, prostate cancer, apoptosis therapies to better understand and to detect the onset of PC. A diet rich in fruits and vegetables has been reported to reduce the risk of common types of cancer and may prove useful in cancer prevention. Moreover, since less-differentiated tumors become resistant to a wide variety of cytotoxic drugs, considerable attention has been focused on chemoprevention with natural compounds as a new and alternative approach to cancer control. Epidemiological studies have shown the ability of dietary compounds to act epigenetically against cancer cells and to influence an individual's risk of developing cancer (5). Several natural antioxidants, in particular polyphenols, have been reported to exhibit chemotherapeutic activity both in vivo and in vitro (6-10). EA (2,3,7,8-tetrahydroxy[1]benzopyrano[5,4,3-cde][1]benzopyran-5,10-dione) is a natural polyphenol found, as both free and bound forms, in numerous fruits and vegetables, particularly in pomegranate (11-15). EA exhibits antioxidant and anticarcinogenic properties including inhibition of tumor formation and growth both in vitro and in vivo (16-25). Moreover, EA was found to inhibit human prostate cancer cell invasion (23).

Our previous research demonstrated a dose-dependent cytotoxic effect of EA, resulting in a reduction in the proliferation rate and a marked increase in DNA damage in prostatic cancer cell lines (26). Moreover, EA reduced chromogranin A $(\mathrm{CgA})$ levels and increased p75 nerve growth factor receptor (p75NGFR) expression, resulting in the reversion of prostatic cancer cell lines from a proliferating to a differentiated state (26). Therefore, EA with both anti-proliferative and prodifferentiation properties is promising as a cancer therapeutic agent.

Tumorigenesis is a multistep process activated by various environmental carcinogens, inflammatory agents and tumor promoters. These carcinogens modulate transcription factors, anti-apoptotic proteins, pro-apoptotic proteins, protein kinases, cell cycle proteins, cell adhesion molecules and growth factor signaling pathways. EA was found to inhibit cell growth and induce apoptosis in a variety of cell cultures $(16,18,23)$. A multitude of factors modulate apoptosis including growth factors, intracellular mediators of signal transduction, nuclear proteins regulating gene expression, DNA replication and cell cycle regulatory genes (27-31). Moreover, the implications for ROS regulation are highly significant for cancer therapy. 
Commonly used radio-therapeutic and chemotherapeutic drugs influence cancer outcome through ROS modulation.

The present study examined the involvement of apoptotic markers in the cytotoxic effects exerted by EA on the LNCaP human prostatic cancer cell line. In particular, we investigated the anti-carcinogenic properties of EA by evaluating its ability to induce cell cycle arrest and apoptosis. We evaluated mTOR, SIRT1, $\beta$-catenin, HUR, AIF, caspase-3, p21, IL-6 and TGF- $\beta$. In addition we examined the effects of EA on the cell cycle and showed that EA regulates apoptosis in the LNCaP prostatic cancer cell line.

\section{Materials and methods}

Cell culture and treatments. Frozen LNCaP cells were purchased from the American Type Culture Collection (Rockville, MD, USA). After thawing, LNCaP cells were re-suspended in RPMI-1640 medium (Sigma-Aldrich, St. Louis, MO, USA), supplemented with $10 \%$ heat inactivated fetal bovine serum (FBS) and 1\% antibiotic/antimycotic solution (both from Invitrogen Life Technologies, Carlsbad, CA, USA). The cells were plated at a density of $1-5 \times 10^{6}$ cells/ T75 flask. Cell cultures were maintained at $37^{\circ} \mathrm{C}$ in a $5 \%$ $\mathrm{CO}_{2}$ incubator, and the medium was changed after 3-4 days. Subconfluent cells were treated for $48 \mathrm{~h}$ with 2 different concentrations (25 and $50 \mu \mathrm{M}$ ) of freshly prepared EA dissolved in dimethyl sulfoxide (DMSO). Control groups received DMSO alone.

Immunoblot analysis. Cells were cultured in T75 flasks for $48 \mathrm{~h}$. They were then washed with PBS and trypsinized $(0.05 \%$ trypsin w/v with $0.02 \%$ EDTA). The pellets were lysed in buffer (50 mM Tris-HCl, $10 \mathrm{mM}$ EDTA, 1\% v/v Triton X-100, $1 \%$ PMSF, $0.05 \mathrm{mM}$ pepstatin A and $0.2 \mathrm{mM}$ leupeptin) and after mixing with sample loading buffer $(50 \mathrm{mM}$ Tris- $\mathrm{HCl}$, $10 \% \mathrm{w} / \mathrm{v}$ SDS, $10 \% \mathrm{v} / \mathrm{v}$ glycerol, $10 \% \mathrm{v} / \mathrm{v} 2$-mercaptoethanol and $0.04 \%$ bromophenol blue) at a ratio of $4: 1$, were boiled for $5 \mathrm{~min}$. Samples (20 $\mu \mathrm{g}$ proteins) were loaded onto 8 or $12 \%$ SDS-polyacrylamide (SDS-PAGE) gels and subjected to electrophoresis $(120 \mathrm{~V}, 90 \mathrm{~min})$. The separated proteins were transferred to nitrocellulose membranes (Bio-Rad, Hercules, CA, USA). After transfer, the blots were incubated with Li-Cor blocking buffer for $1 \mathrm{~h}$, followed by overnight incubation with a 1:1,000 dilution of the primary antibody. Primary polyclonal antibodies directed against AIF, $\beta$-catenin, p-mTOR, SIRT-1, caspase- 3 and p21 were purchased from Cell Signaling Technology, Inc. (Danvers, MA, USA) while HuR and TGF- $\beta$ were purchased from Santa Cruz Biotechnology, Inc. (Dallas, TX, USA). After washing with TBS, the blots were incubated for $1 \mathrm{~h}$ with the secondary antibody $(1: 1,000)$. Protein detection was carried out using a secondary infrared fluorescent dye-conjugated antibody absorbing at 800 and $700 \mathrm{~nm}$ as described below. The blots were visualized using an Odyssey Infrared imaging scanner (LI-COR Biosciences) and quantified by densitometric analysis performed after normalization with $\beta$-actin (Santa Cruz). Results are expressed as arbitrary units (A.U.).

Cell cycle analysis. Cells were cultured as previously described, fixed in $70 \%$ ethanol overnight at $-20^{\circ} \mathrm{C}$ and washed with phosphate-buffered saline (PBS). Aliquots of $1 \times 10^{6}$ cells were re-suspended in $1 \mathrm{ml}$ of PBS containing $1 \mathrm{mg} / \mathrm{ml}$ of RNase A and $0.5 \mathrm{mg} / \mathrm{ml}$ propidium iodide (PI). After a $30-\mathrm{min}$ incubation, the cells were analyzed by flow cytometry using a FACScan flow cytometer (FACSCalibur; BD Biosciences, Franklin Lakes, NJ, USA) and evaluated by fluorescenceactivated cell sorting (FACS) analysis to identify the cells at different stages of the cell cycle.

IL-6 measurements. IL-6 levels were determined in the culture supernatant using an ELISA kit (AssayGate Inc., Ijamsville, MD, USA). The assays were performed according to the manufacturer's guidelines. Results are expressed as $\mathrm{pg} / \mathrm{ml}$.

In-cell western blotting. Cells were seeded in a 96-well cell culture plate. After a 48 -h treatment with 25 or $50 \mu \mathrm{M} \mathrm{EA}$, cells were washed in PBS and directly fixed with $4 \%$ of paraformaldehyde (PFA) in PBS for 20 min. Cells were permeabilized with $0.2 \%$ Triton X-100, blocked with Li-Cor blocking buffer for $60 \mathrm{~min}$ at room temperature, followed by overnight incubation with rabbit HO-1 (1:500) and mouse $\beta$-actin primary antibody $(1: 1,000) . \beta$-actin was used as a housekeeping gene to normalize the HO-1 signal for the cell number. After 3 washes, protein detection was carried out using a secondary infrared fluorescent dye-conjugated antibody absorbing at 800 or $700 \mathrm{~nm}$. The whole plate was visualized using an Odyssey Infrared imaging scanner with a 700-nm fluorophore (red dye) and 800-nm fluorophore (green dye). Relative fluorescence units from the scanning allowed a quantitative analysis of the proteins.

ROS measurement. Determination of ROS was performed using a fluorescent probe 2',7'-dichlorofluorescein diacetate (DCFH-DA), as previously described (32). The fluorescence [corresponding to the oxidized radical species 2',7'-dichlorofluorescein (DCF)] was monitored spectrofluorometrically (excitation, $\lambda=488 \mathrm{~nm}$; emission, $\lambda=525 \mathrm{~nm}$ ). Thus, the intensity of fluorescence was proportional to the levels of oxidant species. The results are reported as fluorescence intensity/mg protein. Protein content was measured according to the method described by Bradford (33).

Statistical analyses. Statistical significance between experimental groups was determined by the Fisher's method of analysis of multiple comparisons $(\mathrm{p}<0.05)$. For comparisons among treatment groups, the null hypothesis was tested by a 2-factor ANOVA for multiple groups or unpaired t-test for 2 groups. Data are presented as means \pm SD.

\section{Results}

Effect of EA on $\beta$-catenin, $p$-mTOR, HuR and SIRT1 expression. We assessed the levels of $\beta$-catenin, p-mTOR, and SIRT1 after $48 \mathrm{~h}$ of culture in the presence of EA. As shown in Fig. 1, EA treatment $(25$ and $50 \mu \mathrm{M})$ resulted in a decrease in both $\beta$-catenin and $\mathrm{p}$-mTOR protein expression $(\mathrm{p}<0.05)$. Similarly, EA exposure showed a significant $(\mathrm{p}<0.05)$ reduction in the RNA-binding protein HuR and consequently in SIRT1 $(\mathrm{p}<0.05) . \mathrm{m}-\mathrm{TOR}$ protein expression remained unchanged upon EA treatment (data not shown). 
B

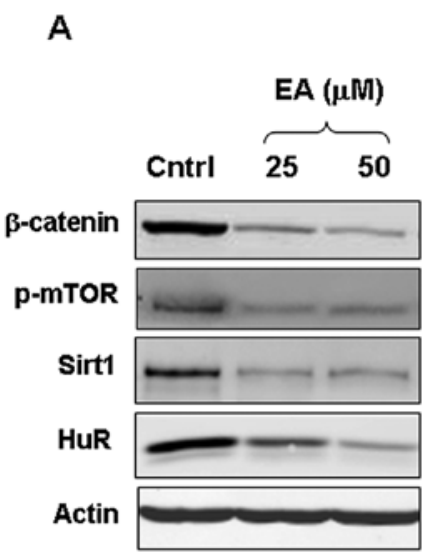

A

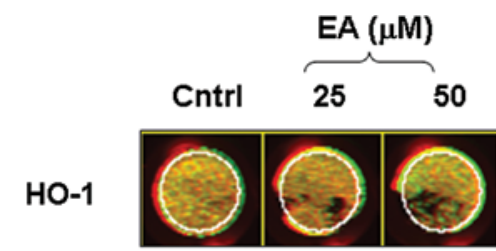

B

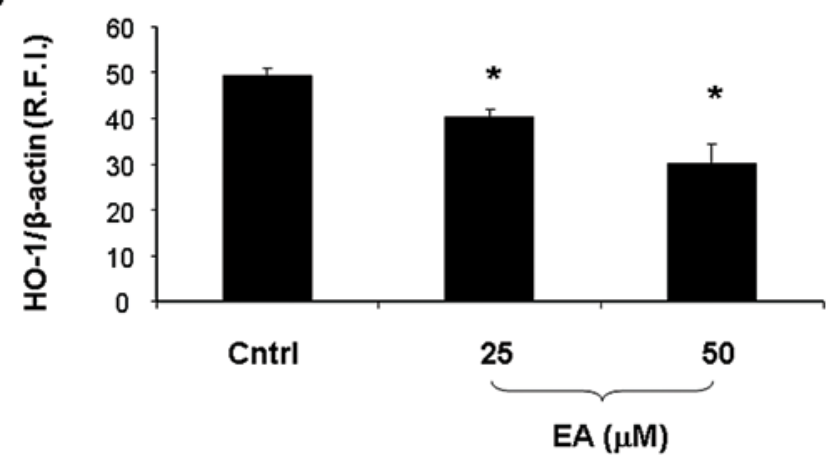

Figure 2. (A) Representative image of HO-1 protein expression in cultured LNCaP cells by in-cell western blotting. (B) Effect of 25 and $50 \mu \mathrm{M}$ EA on HO-1 expression in cultured LNCaP cells. Results are expressed as relative fluorescence intensity (R.F.I.) and represent the means \pm SD of 4 experiments performed in triplicate. " $\mathrm{p}<0.005$, significant result of 25 and $50 \mu \mathrm{M}$ EA vs. control. EA, ellagic acid; HO-1, heme oxygenase-1; Cntrl, control.

Effect of EA on HO-1 expression. HO-1 protein levels were examined by in-cell western blot analysis, to quantify total endogenous cellular protein (Fig. 2). LNCaP cells treated with EA $(25$ and $50 \mu \mathrm{M})$ showed a marked decrease $(\mathrm{p}<0.005)$ in HO-1 fluorescence. HO-1 values were background subtracted from wells treated only with secondary antibody, and then normalized to the cell number by dividing the total actin fluorescence signal.

Effect of EA on AIF, caspase-3, p21 and TGF- $\beta$ expression. Fig. 3 shows the densitometric analysis of AIF, caspase-3, p21 and TGF- $\beta$ expression in untreated and EA-treated LNCaP cells. EA treatment induced a significant $(\mathrm{p}<0.05)$ decrease in total AIF, caspase- 3 and TGF- $\beta$ expression. In contrast $\mathrm{p} 21$ expression was increased $(\mathrm{p}<0.05)$ in the EA-treated group when compared to the controls. Immunoblot analysis showed an increase $(\mathrm{p}<0.05)$ in cleaved-AIF and cleaved-caspase- 3 in cells treated with EA.

ROS levels. As shown in Fig. 4, exposure of $\mathrm{LNCaP}$ cells to both 25 and $50 \mu \mathrm{M}$ EA resulted in a significant increase $(\mathrm{p}<0.005)$ in ROS levels when compared to the untreated cells. The effect appeared to be dose dependent and did not reach a plateau at the doses examined.

Effect of EA on IL-6 levels. The effect of EA on IL-6 levels is shown in Fig. 5. EA treatment induced a significant $(\mathrm{p}<0.05)$ concentration-dependent decrease IL-6 in levels when compared to the control cells.

Cell cycle analysis. Flow cytometric analysis of the cell cycle distribution is shown in Fig. 6. Our results revealed that EA $(50 \mu \mathrm{M})$ induced a slight but significant $(\mathrm{p}<0.005)$ increase in the percentage of cells in the $G_{0} / G_{1}$ or resting phase, a limited but significant $(p<0.005)$ decrease in the percentage of cells in the $S$ (or synthetic) and in the $G_{2} / M$ (or mitotic) phases with concomitant increase $(\mathrm{p}<0.005)$ in the percentage of apoptotic 


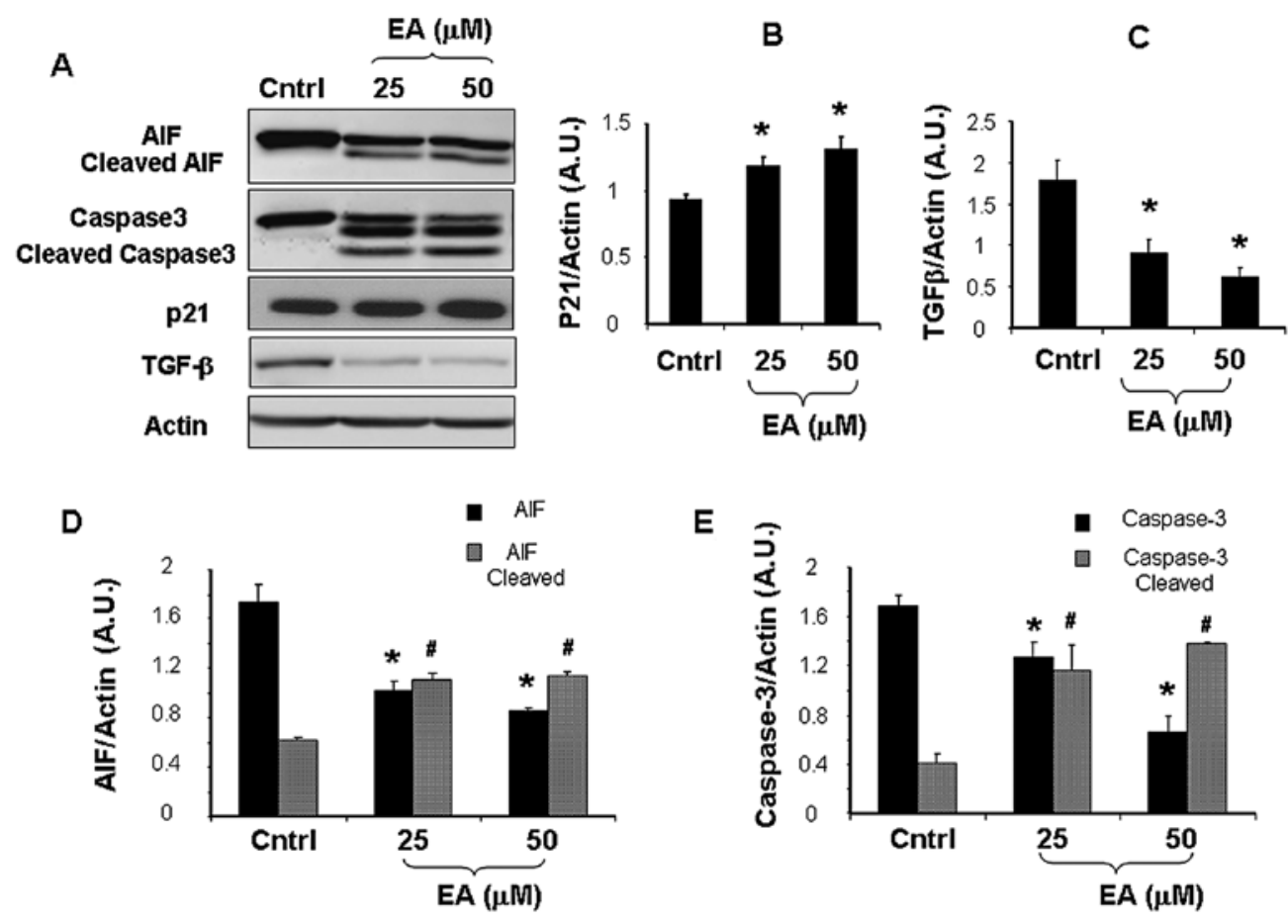

Figure 3. (A) Representative western blotting of AIF, caspase-3, p21, TGF- $\beta$ protein expression in cultured LNCaP cells. (B-E) Effect of EA ( 25 and $50 \mu \mathrm{M})$ on AIF, caspase-3, p21, TGF- $\beta$ expression in cultured LNCaP cells. Results are expressed as arbitrary units (A.U.), and represent the means \pm SD of 4 experiments performed in triplicate. ${ }^{*} \mathrm{p}<0.05$, significant result of 25 and $50 \mu \mathrm{M} \mathrm{EA}$ vs. (black) control; ${ }^{*} \mathrm{p}<0.05$, significant result of 25 and $50 \mu \mathrm{M}$ EA vs. (grey) control. EA, ellagic acid; AIF, apoptosis-inducing factor; TGF- $\beta$, transforming growth factor- $\beta$; Cntrl, control.

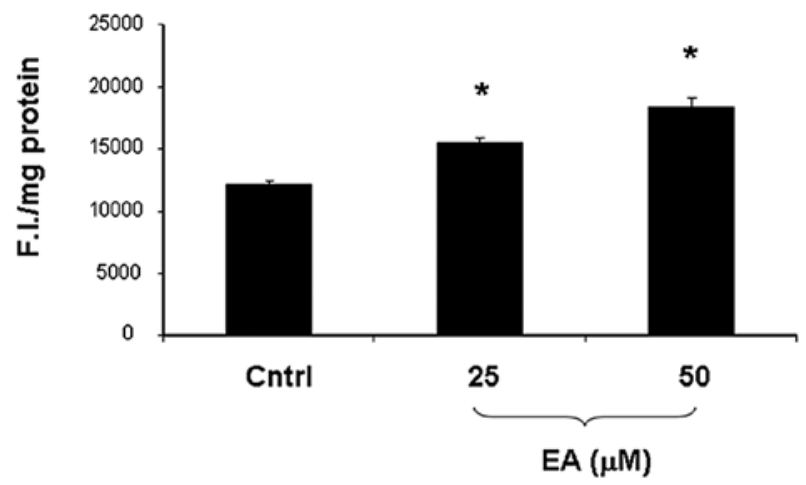

Figure 4. Intracellular oxidants in LNCaP cells untreated and treated for $48 \mathrm{~h}$ with EA at different concentrations $(25$ and $50 \mu \mathrm{M})$. Values represent the means \pm SD of 4 experiments performed in triplicate. " $\mathrm{p}<0.005$, significant result vs. untreated control cells. EA, ellagic acid; Cntrl, control.

cells. EA at $25 \mu \mathrm{M}$ did not induce any modification in cell cycle distribution (data not shown).

\section{Discussion}

Prostrate cancer is a chronic disease that develops from a small lesion to clinical manifestation over an extended period of time. However, once the disease is metastatic, patient prognosis is poor. Thus, the development of new strategies to fight $\mathrm{PC}$ has become an important therapeutic mission. The administration of both synthetic and naturally occurring agents to suppress, reverse and delay carcinogenesis, is increasingly being touted as an effective approach for the management of

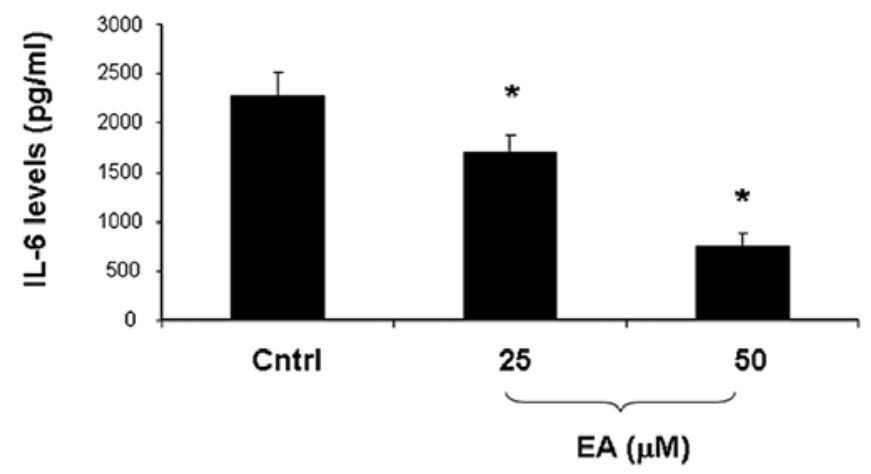

Figure 5. IL-6 levels in LNCaP cells untreated and treated for $48 \mathrm{~h}$ with EA at different concentrations ( 25 and $50 \mu \mathrm{M})$. Values represent the means \pm SD of 4 experiments performed in triplicate. ${ }^{*} \mathrm{p}<0.05$, significant result vs. untreated control cells. IL-6, interleukin-6; EA, ellagic acid; Cntrl, control.

prostatic neoplasia (34-37). In recent years, naturally occurring antioxidant compounds present in the human diet have gained considerable attention as cancer-chemopreventive and chemotherapeutic agents (34,36-38). As previously reported (26), naturally occurring polyphenol EA is regarded as a promising new class of cancer therapeutic agents, with both anti-proliferative and pro-differentiating properties.

$\beta$-catenin is a subunit of a protein complex acting as a signal transducer, and aberrant accumulation of intracellular $\beta$-catenin is a well-recognized characteristic of several types of cancers, including prostate, colon and liver (39-42). The reduction in $\beta$-catenin levels, found in the present study, strongly suggests that this represents a potential mechanism implicated in the anti-proliferative effects of EA. 
A

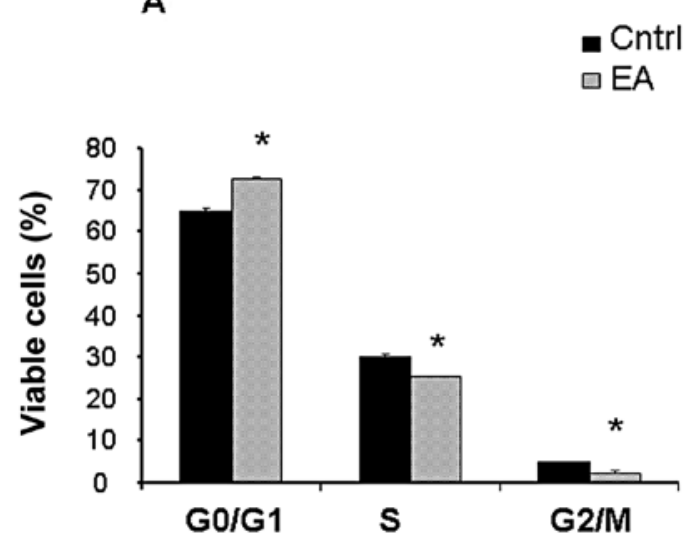

B

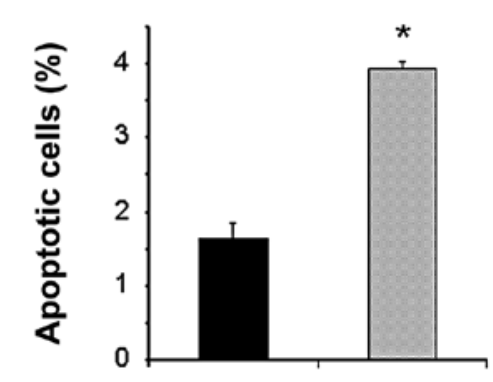

Figure 6. Effect of EA $(50 \mu \mathrm{M})$ on cell cycle distribution as determined by FACS analysis. (A) Percentage of viable cells. (B) Percentage of apoptotic cells. Values are representative from triplicate experiments \pm SD. ${ }^{*} p<0.005$, significant result vs. untreated control cells. EA, ellagic acid; FACS, fluorescenceactivated cell sorting; Cntrl, control.

We showed that EA treatment exerts anti-proliferative effects by reducing intracellular levels of $\beta$-catenin. We previously demonstrated that EA reduced Akt activation/phosphorylation in prostate cancer cell lines. The capacity of p-Akt to phosphorylate/activate mTOR has been described in several cancer cell lines (43-45). Dysregulation of the mTOR pathway occurs in many types of cancers including prostate (43). The inhibition of mTOR activation is considered as a potential target for the development of anticancer therapeutics (43-49). In view of these observations, the significant reduction in mTOR activation, observed in the present study, indicates that EA exerts an anti-proliferative effect by reducing PI3K/ Akt downstream signaling through inhibition of mTOR phosphorylation. In addition, acetylation of Akt blocks Akt binding to $\mathrm{PIP}_{3}$, thereby preventing membrane localization and phosphorylation of Akt. Deacetylation by SIRT1 enhances Akt binding to $\mathrm{PIP}_{3}$ and promotes activation/phoshorylation (50).

SIRT1 functions as an oncogenic protein and plays a role in tumorigenesis (51). SIRT1 is overexpressed in human PC cells (DU145, LNCaP, 22Rv1 and PC3) when compared to normal prostate epithelial cells (PrEC), and inhibition of SIRT1 results in anti-proliferative effects in human PC cells. SIRT1 was found to be overexpressed in human PC tissues when compared with adjacent normal prostate tissue (52). A link between SIRT1 and HuR levels and the anti-apoptotic influence of these 2 proteins (53) has been reported. The RNA-binding protein HuR regulates the stability of many target mRNAs, including SIRT1 mRNA. The reduction in SIRT1 and HuR, observed in the present study following EA treatment, suggests that EA may induce apoptosis via the reduction of the anti-apoptotic proteins SIRT1 and HuR. Moreover, HO-1 translation was found to be diminished in HuR-depleted cells (54). An increase in HO-1 protein levels is associated with a parallel increase in EC-SOD, eNOS (55), increased activation of Akt and an increase in mitochondrial function. HuR promotes HO-1 expression through mRNA stabilization and translational upregulation. Our results confirmed that decreased levels of HuR, after EA treatment, were associated with a reduction in $\mathrm{HO}-1$ protein expression suggesting that HO-1 is a focal target in cancer treatment. Thus, the anti-proliferative effect of EA includes the inactivation of PI3K/Akt signaling cascade, i.e. the inhibition of Akt, mTOR and SIRT1, a decrease in HO-1 levels and, consequently, the activation of the mitochondrial-mediated apoptotic pathway.

AIF is a flavoprotein anchored to the mitochondrial inner membrane. Under physiological conditions, AIF exhibits NADH oxidase activity, important for mitochondrial respiration (56). A previous study with mice characterized by reduced AIF expression, the 'Harlequin' (Hq) mice, suggested that AIF may also protect against oxidative stress (57). Although mislocalization of the AIF protein leads to nuclear condensation and apoptosis, in vivo models of AIF loss result in oxidative stress and neuronal degeneration (57). Upon a specific death signal, AIF is cleaved at the $\mathrm{N}$-terminus releasing the protein from its membrane anchor (58). AIF translocation from the cytosol to the nucleus results in chromatin condensation and large-scale DNA fragmentation, and apoptotic cell death (59) in a caspase-independent manner (60). We noted a decrease in AIF expression and an increase in cleaved AIF upon exposure of the LNCaP cells to EA. The observation that EA modulates AIF expression has at least 2 important conceptual implications. Firstly, EA has a pro-oxidant potential; secondly, a direct link exists between EA and the induction of cleaved AIF followed by activation of the apoptotic pathways. In addition, cancer chemopreventive agents induce apoptosis through ROS generation and disruption of redox homeostasis leading to the activation of the caspase cascade $(61,62)$. In agreement with previous findings (63), our results showed that EA increased ROS levels and activation of caspases, as demonstrated by a decrease in caspase- 3 with a concomitant increase of its cleaved form. Therefore, EA-induced ROS production and activation of caspase-3 may be due to AIF cleavage.

IL-6 is a multifunctional cytokine and a major activator of different signaling pathways. It regulates growth of prostate cancer (64) and inhibits apoptosis in several prostate cancer cell lines (65). Increased IL-6 levels, found in prostate cancer, may be due to enhanced expression of TGF- $\beta$ (66), which regulates cell proliferation, phenotype and matrix synthesis. In cancer cells, TGF- $\beta$ acts on the surrounding stromal, immune, endothelial and smooth-muscle cells, causing 
immunosuppression and angiogenesis, resulting in a more invasive form of cancer (67). We demonstrated in the present study that EA reduces both TGF- $\beta$ and IL- 6 levels. Overall, EA induces both caspase-independent and caspase-dependent apoptotic cell death. EA caused a significant increase in p21 expression, a negative regulator of the cell cycle. In addition, FACS analysis revealed that EA treatment induced a different distribution of cells in the various phases of the cell cycle, with a concomitant increase in apoptotic cells. Moreover, in addition to pro-differentiating properties, the cytotoxic effects of EA may be due to its ability to modulate the expression of multiple apoptotic markers. In conclusion, the present study strongly supports the hypothesis that EA regulates apoptosis through activation/inactivation of several proteins involved in tumor growth and cell invasiveness. EA may represent a new approach and a highly effective strategy for reducing the occurrence of prostate cancer.

\section{References}

1. Ferlay J, Parkin DM and Steliarova-Foucher E: Estimates of cancer incidence and mortality in Europe in 2008. Eur J Cancer 46: 765-781, 2010

2. American Cancer Society: Prostate Cancer Statistics 2013 http://www.cancer.org. Accessed: May 20, 2013.

3. American Society of Clinical Oncology Prostate Cancer Statistics. http://www.cancer.net/prostate. Accessed: May 20, 2013.

4. Imamoto T, Suzuki H, Akakura K, Komiya A, Nakamachi H, Ichikawa T, Igarashi T and Ito H: Pretreatment serum level of testosterone as a prognostic factor in Japanese men with hormonally treated stage D2 prostate cancer. Endocr J 48: 573-578, 2001

5. Chen J and Xu X: Diet, epigenetic, and cancer prevention. Adv Genet 71: 237-255, 2010.

6. Kang NJ, Shin SH, Lee HJ and Lee KW: Polyphenols as small molecular inhibitors of signaling cascades in carcinogenesis. Pharmacol Ther 130: 310-324, 2011.

7. Weng CJ and Yen GC: Chemopreventive effects of dietary phytochemicals against cancer invasion and metastasis: phenolic acids, monophenol, polyphenol, and their derivatives. Cancer Treat Rev 38: 76-87, 2012.

8. Russo A, Piovano M, Lombardo L, Vanella L, Cardile V and Garbarino J: Pannarin inhibits cell growth and induces cell death in human prostate carcinoma DU-145 cells. Anticancer Drugs 17: 1163-1169, 2006

9. Yim D, Singh RP, Agarwal C, Lee S, Chi H and Agarwal R: A novel anticancer agent, decursin, induces G1 arrest and apoptosis in human prostate carcinoma cells. Cancer Res 65: 1035-1044, 2005.

10. Cardile V, Scifo C, Russo A, Falsaperla M, Morgia G, Motta M, Renis M, Imbriani E and Silvestre G: Involvement of HSP70 in resveratrol-induced apoptosis of human prostate cancer. Anticancer Res 23: 4921-4926, 2003.

11. Aviram M, Dornfield L, Rosenblat M, Volkova N, Kaplan M, Coleman R, Hayek T, Presser D and Fuhrman B: Pomegranate juice consumption reduces oxidative stress, atherogenic modifications to LDL, and platelet aggregation: studies in humans and in atherosclerotic apolipoprotein E-deficient mice. Am J Clin Nutr 71: 1062-1076, 2000.

12. Kaplan M, Hayek T, Raz A, Coleman R, Dornfeld L, Vaya J and Aviram M: Pomegranate juice supplementation to atherosclerotic mice reduces macrophage lipid peroxidation, cellular cholesterol accumulation and development of atherosclerosis. J Nutr 131: 2082-2089, 2001.

13. Kim ND, Mehta R, Yu W, Neeman I, Livney T, Amichay A, Poirier D, Nicholls P, Kirby A, Jiang W, Mansel R, Ramachandran C, Rabi T, Kaplan B and Lansky E: Chemopreventive and adjuvant therapeutic potential of pomegranate (Punica granatum) for human breast cancer. Breast Cancer Res Treat 71: 203-217, 2002.

14. Cerdá B, Cerón JJ, Tomás-Barberán FA and Espín JC: Repeated oral administration of high doses of pomegranate ellagitannin punicalagin to rats for 37 days is not toxic. J Agric Food Chem 51: 3493-3501, 2003.
15. Cerdá B, Llorach R, Cerón JJ, Espín JC and Tomás-Barberán FA: Evaluation of the bioavailability and metabolism in the rat of punicalagin, an antioxidant polyphenol from pomegranate juice. Eur J Nutr 42: 18-28, 2003.

16. Narayanan BA, Geoffrey O, Willingham MC, Re GG and Nixon DW: p53/p21(WAF1/CIP1) expression and its possible role in G1 arrest and apoptosis in ellagic acid-treated cancer cells. Cancer Lett 136: 215-221, 1999.

17. Khanduja KL, Gandhi RK, Pathania V and Syanl N: Prevention of $\mathrm{N}$-nitrosodiethylamine-induced lung tumorigenesis by ellagic acid and quercetin in mice. Food Chem Toxicol 37: 313-318, 1999.

18. Mertens-Talcott SU, Talcott ST and Percival SS: Low concentrations of quercetin and ellagic acid synergistically influence proliferation, cytotoxicity and apoptosis in MOLT-4 human leukemia cells. J Nutr 133: 2669-2674, 2003.

19. Heber D: Multitargeted therapy of cancer by ellagitannins. Cancer Lett 269: 262-268, 2008.

20. Seeram NP, Adams LS, Henning SM, Niu Y, Zhang Y, Nair MG and Heber D: In vitro antiproliferative, apoptotic and antioxidant activities of punicalagin, ellagic acid and a total pomegranate tannin extract are enhanced in combination with other polyphenols as found in pomegranate juice. J Nutr Biochem 16: 360-367, 2005.

21. Seeram NP, Aronson WJ, Zhang Y, Henning SM, Moro A, Lee RP, Sartippour M, Harris DM, Rettig MB, Suchard MA, Pantuck AJ, Belldegrun A and Heber D: Pomegranate ellagitannin-derived metabolites inhibit prostate cancer growth and localize to the mouse prostate gland. J Agric Food Chem 55: 7732-7737, 2007.

22. Falsaperla M, Morgia G, Tartarone A, Ardito R and Romano G: Support ellagic acid therapy in patients with hormone refractory prostate cancer (HRPC) on standard chemotherapy using vinorelbine and estramustine phosphate. Eur Urol 47: 449-455, 2005.

23. Lansky EP, Harrison G, Froom P and Jiang WG: Pomegranate (Punica granatum) pure chemicals show possible synergistic inhibition of human PC-3 prostate cancer cell invasion across Matrigel. Invest New Drugs 23: 121-122, 2005.

24. Sartippour MR, Seeram NP, Rao JY, Moro A, Harris DM, Henning SM, Firouzi A, Rettig MB, Aronson WJ, Pantuck AJ and Heber D: Ellagitannin-rich pomegranate extract inhibits angiogenesis in prostate cancer in vitro and in vivo. Int $\mathrm{J}$ Oncol 32: 475-480, 2008

25. Umesalma $S$ and Sudhandiran G: Ellagic acid prevents rat colon carcinogenesis induced by 1,2 dimethyl hydrazine through inhibition of AKT-phosphoinositide-3 kinase pathway. Eur J Pharmacol 660: 249-258, 2011.

26. Vanella L, Barbagallo I, Acquaviva R, Di Giacomo C, Cardile V, Abraham NG and Sorrenti V: Ellagic acid: cytodifferentiating and antiproliferative effects in human prostatic cancer cell lines. Curr Pharm Des 19: 2728-2736, 2013.

27. Fisher ED: Apoptosis in cancer therapy: crossing the threshold. Cell 78: 539-542, 1994.

28. Hartwell HL and Kastan MB: Cell cycle control and cancer. Science 266: 1821-1828, 1994.

29. Thompson CB: Apoptosis in the pathogenesis and treatment of disease. Science 267: 1456-1462, 1995.

30. Steller H: Mechanisms and genes of cellular suicide. Science 267: 1445-1449, 1995.

31. Hunter T: Oncoprotein networks. Cell 88: 333-346, 1997.

32. Acquaviva R, Di Giacomo C, Sorrenti V, Galvano F, Santangelo R, Cardile V, Gangia S, D'Orazio N, Abraham NG and Vanella L: Antiproliferative effect of oleuropein in prostate cell lines. Int J Oncol 41: 31-38, 2012.

33. Bradford MM: A rapid and sensitive method for the quantitation of microgram quantities of protein utilizing the principle of protein-dye binding. Anal Biochem 72: 248-254, 1976.

34. Hong WK and Sporn MB: Recent advances in chemoprevention of cancer. Science 278: 1073-1077, 1997.

35. Parnes HL, Thompson IM and Ford LG: Prevention of hormonerelated cancers: prostate cancer. J Clin Oncol 23: 368-377, 2005.

36. Mukhtar H and Ahmad N: Cancer chemoprevention: future holds in multiple agents. Toxicol Appl Pharmacol 158: 207-210, 1999.

37. Surh YJ: Cancer chemoprevention with dietary phytochemicals Nat Rev Cancer 3: 768-780, 2003.

38. Greenwald P: Lifestyle and medical approaches to cancer prevention. Recent Results Cancer Res 166: 1-15, 2005.

39. Barker $\mathrm{N}$ and Clevers $\mathrm{H}$ : Catenins, Wnt signaling and cancer. Bioessays 22: 961-965, 2000 
40. Fearnhead NS, Britton MP and Bodmer WF: The ABC of APC. Hum Mol Genet 10: 721-733, 2001.

41. Karim R, Tse G, Putti T, Scolyer R and Lee S: The significance of the Wnt pathway in the pathology of human cancers. Pathology 36: 120-128, 2004.

42. Gwak J, Lee JH, Chung YH, Song GY and Oh S: Small moleculebased promotion of PKC $\alpha$-mediated $\beta$-catenin degradation suppresses the proliferation of CRT-positive cancer cells. PLoS One 7: e46697, 2012.

43. Pratheeshkumar P, Budhraja A, Son YO, Wang X, Zhang Z, Ding S,Wang L, Hitron A, Lee JC, Xu M, Chen G, Luo J and Shi X: Quercetin inhibits angiogenesis mediated human prostate tumor growth by targeting VEGFR-2 regulated AKT/mTOR/P70S6K signaling pathways. PLoS One 7: e47516, 2012.

44. Diersch S, Wenzel P, Szameitat M, Eser P, Paul MC, Seidler B, Eser S, Messer M, Reichert M, Pagel P, Esposito I, Schmid RM, Saur D and Schneider G: Efemp1 and p2 $7^{\mathrm{Kipl}}$ modulate responsiveness of pancreatic cancer cells towards a dual PI3K/mTOR inhibitor in preclinical models. Oncotarget 4: 277-288, 2013.

45. Vinayak $S$ and Carlson RW: mTOR inhibitors in the treatment of breast cancer. Oncology 27: 38-44, 2013.

46. Fasolo A and Sessa C: mTOR inhibitors in the treatment of cancer. Expert Opin Investig Drugs 17: 1717-1734, 2008.

47. Jo MJ, Kim HR and Kim GD: The anticancer effects of Saccharina japonica on 267B1/K-ras human prostate cancer cells. Int J Oncol 41: 1789-1797, 2012.

48. Adhami VM, Syed DN, Khan N and Mukhtar H: Dietary flavonoid fisetin: a novel dual inhibitor of PI3K/Akt and mTOR for prostate cancer management. Biochem Pharmacol 84 1277-1281, 2012

49. Fagone P, Donia M, Mangano K, Quattrocchi C, Mammana S, Coco M, Libra M, McCubrey JA and Nicoletti F: Comparative study of rapamycin and temsirolimus demonstrates superimposable anti-tumour potency on prostate cancer cells. Basic Clin Pharmacol Toxicol 112: 63-69, 2013.

50. Sundaresan NR, Pillai VB, Wolfgeher D, Samant S, Vasudevan $P$, Parekh V, Raghuraman H, Cunningham JM, Gupta M and Gupta MP: The deacetylase SIRT1 promotes membrane localization and activation of Akt and PDK1 during tumorigenesis and cardiac hypertrophy. Sci Signal 4: ra46, 2011.

51. Chen HC, Jeng YM, Yuan RH, Hsu HC and Chen YL: SIRT1 promotes tumorigenesis and resistance to chemotherapy in hepatocellular carcinoma and its expression predicts poor prognosis Ann Surg Oncol 19: 2011-2019, 2012.

52. Jung-Hynes B, Nihal M, Zhong W and Ahmad N: Role of sirtuin histone deacetylase SIRT1 in prostate cancer. A target for prostate cancer management via its inhibition? J Biol Chem 284: 3823-3832, 2009.

53. Abdelmohsen K, Pullmann R Jr, Lal A, Kim HH, Galban S, Yang X, Blethrow JD, Walker M, Shubert J, Gillespie DA, Furneaux $\mathrm{H}$ and Gorospe M: Phosphorylation of HuR by Chk2 regulates SIRT1 expression. Mol Cell 25: 543-557, 2007.

54. Kuwano Y, Rabinovic A, Srikantan S, Gorospe M and Demple B: Analysis of nitric oxide-stabilized mRNAs in human fibroblasts reveals HuR-dependent heme oxygenase 1 upregulation. Mol Cell Biol 29: 2622-2635, 2009.
55. Kruger AL, Peterson S, Turkseven S, Kaminski PM, Zhang FF, Quan S, Wolin MS and Abraham NG: D-4F induces heme oxygenase-1 and extracellular superoxide dismutase, decreases endothelial cell sloughing, and improves vascular reactivity in rat model of diabetes. Circulation 111: 3126-3134, 2005.

56. Miramar MD, Costantini P, Ravagnan L, Saraiva LM, Haouzi D, Brothers G, Penninger JM, Peleato ML, Kroemer G and Susin SA: NADH oxidase activity of mitochondrial apoptosisinducing factor. J Biol Chem 276: 16391-16398, 2001.

57. Klein JA, Longo-Guess CM, Rossmann MP, Seburn KL, Hurd RE, Frankel WN, Bronson RT and Ackerman SL: The harlequin mouse mutation downregulates apoptosis-inducing factor. Nature 419: 367-374, 2002.

58. Otera H, Ohsakaya S, Nagaura Z, Ishihara N and Mihara K: Export of mitochondrial AIF in response to proapoptotic stimuli depends on processing at the intermembrane space. EMBO J 24 : 1375-1386, 2005.

59. Susin SA, Lorenzo HK, Zamzami N, Marzo I, Snow BE, Brothers GM, Mangion J, Jacotot E, Costantini P, Loeffler M, Larochette N, Goodlett DR, Aebersold R, Siderovski DP, Penninger JM and Kroemer G: Molecular characterization of mitochondrial apoptosis-inducing factor. Nature 397: 441-446, 1999.

60. Cregan SP, Fortin A, MacLaurin JG, Callaghan SM, Cecconi F, Yu SW, Dawson TM, Dawson VL Park DS Kroemer G and Slack RS: Apoptosis-inducing factor is involved in the regulation of caspase-independent neuronal cell death. J Cell Biol 158: 507-517, 2002.

61. Ling YH, Liebes L, Zou Y and Perez-Soler R: Reactive oxygen species generation and mitochondrial dysfunction in the apoptotic response to Bortezomib, a novel proteasome inhibitor, in human $\mathrm{H} 460$ non-small cell lung cancer cells. J Biol Chem 278: 33714-33723, 2003.

62. Paradies G, Petrosillo G, Pistolese M and Ruggiero FM: Reactive oxygen species affect mitochondrial electron transport complex I activity through oxidative cardiolipin damage. Gene 286: 135-141, 2002.

63. Malik A, Afaq S, Shahid M, Akhtar K and Assiri A: Influence of ellagic acid on prostate cancer cell proliferation: a caspasedependent pathway. Asian Pac J Trop Med 4: 550-555, 2011.

64. Smith PC, Hobisch A, Lin DL, Culig Z and Keller ET: Interleukin-6 and prostate cancer progression. Cytokine Growth Factor Rev 12: 33-40, 2001

65. Cavarretta IT, Neuwirt H, Untergasser G, Moser PL, Zaki MH, Steiner H, Rumpold H, Fuchs D, Hobisch A, Nemeth JA and Culig Z: The antiapoptotic effect of IL-6 autocrine loop in a cellular model of advanced prostate cancer is mediated by Mcl-1. Oncogene 26: 2822-2832, 2007.

66. Culig Z and Puhr M: Interleukin-6: a multifunctional targetable cytokine in human prostate cancer Mol Cell Endocrinol 360 52-58, 2012.

67. Yang F, Strand DW and Rowley DR: Fibroblast growth factor-2 mediates transforming growth factor- $\beta$ action in prostate cancer reactive stroma. Oncogene 27: 450-459, 2008. 